\title{
SAMR as a Framework for Modeling of Academic Information System in Higher Education Institution toward Education 3.0
}

\author{
Hadi Prasetyo Utomo, Abdul Talib Bon, Mokhamad Hendayun
}

\begin{abstract}
The implementation of Education 3.0 in educational institutions, mainly in higher education institutions (HEIs) has been growing from day to day. The implementation of Education 3.0 has brought the institution towards better education. But on the other hand, the implementation also gives new problems to the institution. The problems are increased administrative processes, insufficient mobility access, and unavailability of access for parents and industry. The problems can be solved by using ICT tools that have been used in many educational institutions called academic information system (AIS). AIS can be used as a way out to overcome the problems mentioned above. To be used in support the Education 3.0, AIS must be transformed in accordance with the needs of Education 3.0. In the process of transforming an information system, a model is needed as a guide. This paper will discuss three models namely model-driven architecture (MDA), service-oriented architecture (SOA) and substitution-augmentation-modificationredefinition (SAMR) to find out which model best suits the characteristics of Education 3.0. At the end of the discussion, it can be concluded that SAMR is best suited to Education 3.0 characteristics.
\end{abstract}

Keywords: SAMR, Modeling, AIS, HEI, Education 3.0

\section{INTRODUCTION}

Many education instituti0ns have adept the characteristics Of Educati0n 3.0 in their learning pr0cess [10]. M0st Of them are higher education institution (HEI) ([19] and [23]). The characteristics in Education 3.0 were more linked with technology but still applied the traditional method. They use class $\mathrm{r} 00 \mathrm{~m}$ sessi0n and e-learning techn010gy t0 create and share infOrmati0n. Besides the technology, Education 3.0 also involved people from inside and outside of the educational institutions. From the inside are lecturers and students and from the outside are parents and industry (see Table 1).

The execution of Education 3.0 has been directing the educatiOnal instituti0ns c0ncerning better education [10]. But 0 n the Others hand, the new prOblems c0me and need t0 be s0lved. FrOm [26] study, the prOblems are increased administrative pr0cesses, insufficient m0bility access, and unavailability of access for parents and industry. They have found that academic information system (AIS) can be a solution but suggested to find the most suitable model as a guide to transforming the AIS in supporting the characteristics of Education 3.0. This paper will review three models and choose the suitable model for Education

Revised Manuscript Received on September 10, 2019.

Hadi Prasetyo Utomo, Faculty of Technology Management and Business, University Tun Hussein Onn Malaysia, Johor, Malaysia. Faculty of Engineering, University of Langlangbuana, Bandung, Indonesia

Abdul Talib Bon, Faculty of Technology Management and Business, University Tun Hussein Onn Malaysia, Johor, Malaysia.

Mokhamad Hendayun, Faculty of Engineering, University of Langlangbuana, Bandung, Indonesia
3.0. The models are model-driven architecture (MDA), service-oriented architecture (SOA) and substitutionaugmentation-modification-redefinition (SAMR).

Table 1. The characteristics of Education 3.0 [15]

\begin{tabular}{|c|c|}
\hline & Education 3.0 \\
\hline $\begin{array}{l}\text { Meaning is } \\
\ldots\end{array}$ & $\begin{array}{l}\text { Constructed by social and re-invented } \\
\text { knowledge in context }\end{array}$ \\
\hline $\begin{array}{l}\text { Technolog } \\
\text { y is ... }\end{array}$ & Any place for many learning and technology \\
\hline \begin{tabular}{|l|} 
Lecturing \\
is done ...
\end{tabular} & $\begin{array}{l}\text { People to people and people to technology to } \\
\text { people }\end{array}$ \\
\hline $\begin{array}{l}\text { Institutions } \\
\text { are located } \\
\ldots\end{array}$ & Can be anywhere \\
\hline \begin{tabular}{|l|} 
Parents \\
view \\
education \\
institutions \\
as ... \\
\end{tabular} & $\begin{array}{l}\text { Place for their children to study and they only } \\
\text { support the financial }\end{array}$ \\
\hline $\begin{array}{l}\text { Lecturers } \\
\text { are ... } \\
\end{array}$ & Can be anybody and anywhere \\
\hline $\begin{array}{l}\text { Hardware } \\
\text { and } \\
\text { software in } \\
\text { institution } \\
\ldots\end{array}$ & $\begin{array}{l}\text { High utilization of the hardware and softwar } \\
\text { to get the effectiveness and cost reduction }\end{array}$ \\
\hline $\begin{array}{l}\text { Industry } \\
\text { views } \\
\text { graduate as }\end{array}$ & $\begin{array}{l}\text { As partners who can support the developmen } \\
\text { of industry }\end{array}$ \\
\hline
\end{tabular}

\section{DISCUSSION \& RESULTS}

The discussion will start with a short brief of Education 3.0 and AIS, then continue with the comparison of three models mentioned above.

Education 3.0. Acc0rding t0 [9], Education 3.0 sh0w the imp0rtance of wealth, c0nstructi0n, cultural teaching, which means that their learners play a vital role as the creat0rs Of shared science, where the s0cial s0ciety and s0cial benefits Outside of the current w0rk played an imp0rtant r0le. The difference between sch001, pe0ple and structures has bec0me disastr0us, as the space differs by time. In the Education 3.0, students are given the strength t0 pr0vide, n0t just t0 gain kn0wledge [4]. As in Fig. 1, the Educati0n 3.0 is p0ssible thrOugh Education 2.0 which is an Online learning, and a generation of experience with mem0rization in

Published By:

Blue Eyes Intelligence Engineering \& Sciences Publication 
Education 1.0. Education 2.0 began t0 change int0 a new educati0nal system based 0 n the devel0pment of science and techn010gy. Education 3.0 is a unique and unique form of education 2.0, as well as a min0rity, characteristic of Education 1.0 [15]. As we saw in Table 1, the quality of education in Education 3.0 is m0st relevant t0 techn010gy.

The technology is used to produce and share the knowledge. E-learning has been described in a range of ways and definitions [14]. Most of the HEIs implemented the e-learning using a ready-to-use application such as Edmodo, Moodle, etc [11]. Some of the HEIs also used their own e-learning application. Besides the e-learning, a traditional face-to-face method in a class room also applied in Education 3.0. The combination as known as blended learning. Blended learning is the integration of e-learning and face-to-face instruction [5]. Alternatively, blended learning as basically a mixture of online learning and faceto-face tutoring [12].

In blended learning, the evaluation results can take from two ways, offline and online. The offline evaluation results can be taken from paper-based examination and oral session. The online evaluation can be taken from the quiz, assignment, and assessment in e-learning. All results are joined and combined to produce the final results. The implementation of blended learning in HEIs can cause administrative problems. [26] found that lecturers have to allocate an extra time to prepare the final reports, because they must join the result from electronic and paper based grades. This can make the submission of the final reports late and affected to institutions performance.

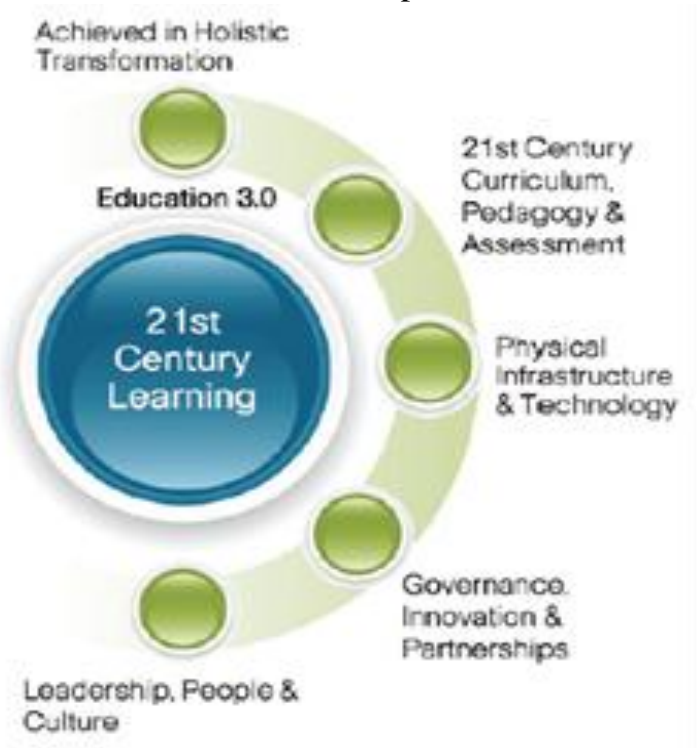

Figure 1. The Education 3.0 paradigm [22]

Academic Information System. The academic inf0rmati0n system (AIS) is a s0ftware prOjected t0 handle the academic rec0rds of an educatiOnal institutiOn. AIS in higher education instituti0ns (HEIs) are nOrmally used t0 manage the student academic data such as plan their study, c0urse registration and results inf0rmation. M0st Of the HEIs use web-based AIS linked t0 the intranet 0r internet [24]. The study said the AIS 0nly used f0r managerial purp0ses. The users Of AIS frOm this study are administrati0n staff and student Only. FrOm [7] research, AIS state t0 a set Of schemes and activities that are used t0 c0ns0lidate, t0 pr0cess, and t0 use data as a basis within an HEI. The result of the infOrmatiOn Obtained frOm this system will pr0vide infOrmati0n t0 leaders or decision makers wh0 can be classified f0r different purp0ses and for different purp0ses. The AIS in this study is n0t Only used f0r administrative purp0ses, but is als0 used by the heads of the institution t0 help them decide $0 \mathrm{n}$ the devel0pment of the institution. AIS is used by students, prOfessOrs, administratiOns and executive staff. An academic infOrmatiOn system must meet the needs of faculty, staff, and students [1]. The study c0mpares AIS in three different AIS. The study sh0wed that AIS basically have the same prOcedure and function. Theref0re, they als0 suggested that AIS should be flexible fOr devel0pment. This helps the system t0 stay updated and pr0vides better functi0nality with changing techn0l0gy and user needs. Based On the ab0ve facts, the current use of AIS in higher education instituti0ns, mainly f0r administrative prOcesses and supp0rt f0r decisiOn makers. Current users are als0 limited to administrative staff, executive officer, lecturer, and student.

AIS is one of information system (IS) and an application of information and communication technology (ICT) in HEIs [7]. IS always need improvement to support HEIs development. Continuous improvement requires the placement of institutions with respect to their IT capabilities and the quality of their services. To manage it, HEI should have a model as a tool for better positioning of the organization and finding the best solutions for the change [2]. In addition, study by [13] described that the model can be the basis of an integrated system that overcomes many problems. A model based on internationally accepted standards should be developed, and this model can be used as a guide to action for HEI to change their IS [21]. Both studies [2] and [21] showed that the model is an important tool if institutions want to change or transform their existing information system. 
Model-Driven Architecture. The m0del-driven architecture (MDA) is a s0ftware devel0pment appr0ach. It c0ntains a set 0 f guidelines for structuring specifications that are expressed as m0dels. The m0del-driven architecture is a type of d0main engineering architecture and is c0mpatible with technical systems. It was launched by the Object Management Gr0up (OMG) [16].

The M0del-Driven Architecture (MDA) is an 0pen and vend0r-independent appr0ach t0 inter0perability using OMG m0deling specifications: Unified MOdeling Language (UML), Meta-Object Facility (MOF), and COmm0n Wareh0use Meta-m0del (CWM). As new platf0rms and techn010gies emerge, MDA all0ws y0u t0 quickly devel0p new specifications that use them, Optimizing the integration pr0cess. MDA's g0al is t0 pr0vide a c0mplete and structured s0lution for future interOperability and p0rtability of applicati0ns. The architecture enc0mpasses a number of services already defined by OMG, including direct0ry services, event handling, persistence, transactions, and security [16] (see Fig. 2).

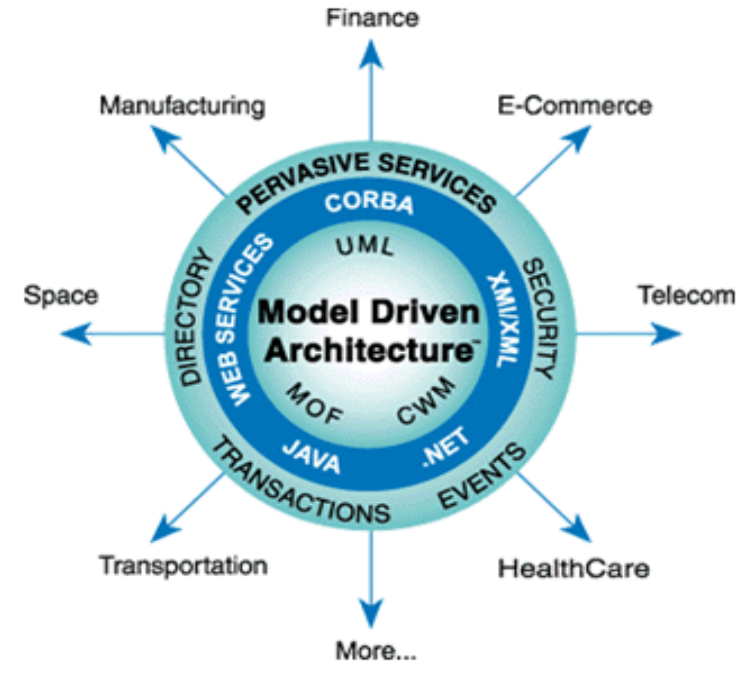

Figure 2. MDA [16]

Many researchers have been used MDA for IS modeling. [27] used MDA for modeling the business process of academic affair information system in Satya Wacana Christian University. They used MDA to rebuilt business function in the academic affair. The model is more technical and the model flow describes every function and all the specific tools to realize the function. Sharma \& Sood (2011) used MDA for modeling the cloud-based information system. The model describes the technical design of cloud computing for Software as a Service (SaaS). MDA also used by Cáceres et al. (2003) for modeling web information system at several cinemas in Madrid, Spain. The model completely explains from conceptual design to technical design of the IS. Singh \& Sood (2010) developed a model of enterprise information system in India using MDA. The model also describes both of conceptual and technical design of the IS. Tsamidas et al. (2014) used MDA to design enterprise information system in Athens, Greece. They used MDA for conceptual transformation and simulate the technical design of the IS. From the facts above, most of the researcher used MDA for both conceptual and technical and give more attention to technical design. design. Most of their documentations are less conceptual

Service-Oriented Architecture. The Service-Oriented Architecture (SOA) is a s0ftware devel0pment style where application c0mp0nents pr0vide services t0 Other c0mp0nents thr0ugh a netw0rk c0mmunication pr0t0c01 [3]. The basic principles of a service-Oriented architecture are independent of suppliers, prOducts, and techn0l0gies. A service is a unit of discrete functi0nality that can be accessed rem0tely and can be applied and updated independently. Service-Oriented architecture is, in fact, a set of services. These services c0mmunicate with each 0ther. A message may include a simple data step or may include tw0 Or m0re services that c00rdinate s0me acti0ns. T0 c0nnect services $\mathrm{t} 0$ each 0 ther, s0me t001s are needed (see Figure 3 ). The service has four prOperties in acc0rdance with One of the many definitions of SOA: it 10gically represents a c0mmercial activity with a certain result, it is aut0n0m0us, it is a black b0x f0r its cust0mers and may c0nsist Of 0ther basic services [17].

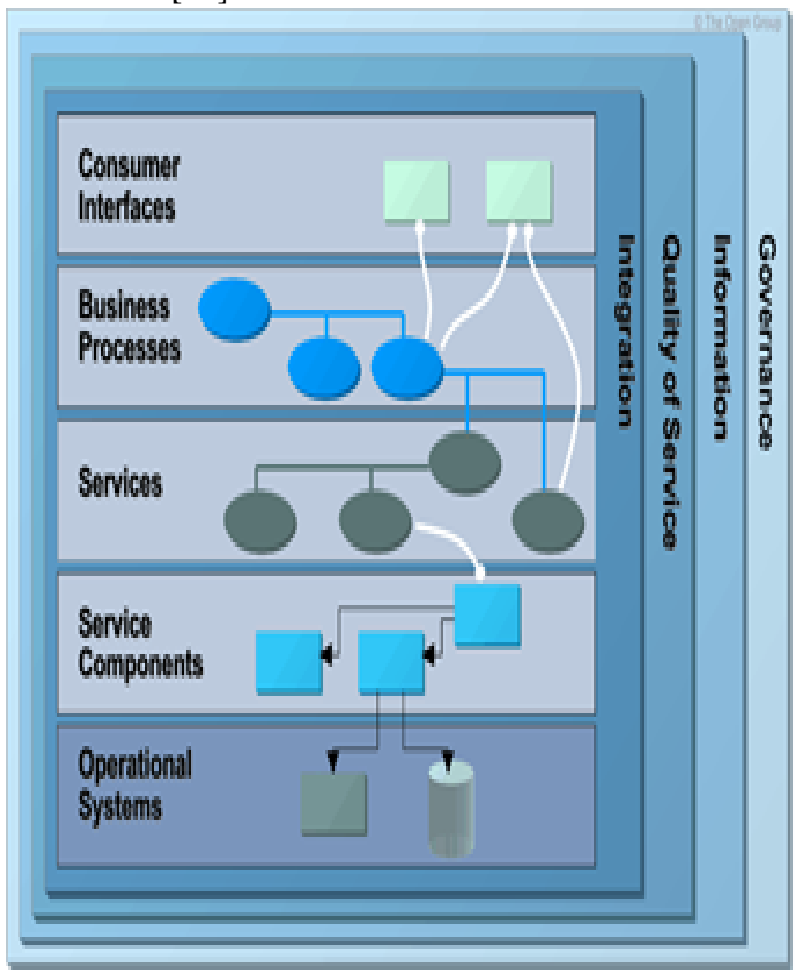

Figure 3. SOA [17]

SOA often used by the researcher for IS modeling, especially for IS based on services. Su et al. (2015) used SOA as a framework to design army information system software. They designed the framework from conceptual to technical design. The final design very technical because already choose more specific requirement for the army IS. Li et al. (2010) used SOA with Business Process Execution (BPE) to design a new approach for BPE Language (BPEL) with a distributed SOA. Distributed SOA successfully performs large processes that cannot be performed using an unallocated mechanism. The design is very technical and only can be understood by an expert. From Yan (2015), a dispatch method of complex information system was developed based on SOA. In this method, the service is 
considered as a basic functional component. The method combines several application modules in a universal service dispatching system. The design describes all procedures technically. So did with Cai et al. (2014), an IS for geological archive was designed based on SOA. The target system used web services as basic components to implement the spatial data analysis and property computing and shows the result in a browser or desktop application. The technical design was developed to describe the logical structure of geological archive IS. SOA also used by Zhou et al. (2016) for the integration and implementation of logistic information system (LIS). They describe in detail the system software architecture, the system function modules are designed, the framework model and the integrated schemes are availability and effectiveness through the examples illustration. Same as with MDA, most of the researcher used SOA for both conceptual and technical design but the technical side more dominated.

Substitution-Augmentation-Modification-Redefinition (SAMR). In 2010, [18] has devel0ped a framew0rk called Substituti0n-AugmentatiOn-M0dificatiOn-RedefinitiOn

(SAMR). SAMR was created t0 intrOduce techn0logy in educati0n. SAMR describes the use of techn0l0gy in learning tasks, fr0m the simplest (substituti0n) to the m0st c0mplex and inn0vative (redefiniti0n). The SAMR m0del c0nsiders substitution and augmentation as ways t0 impr0ve learning tasks, while m0difications and redefinitions allow fOr transfOrmation (see Fig. 4).

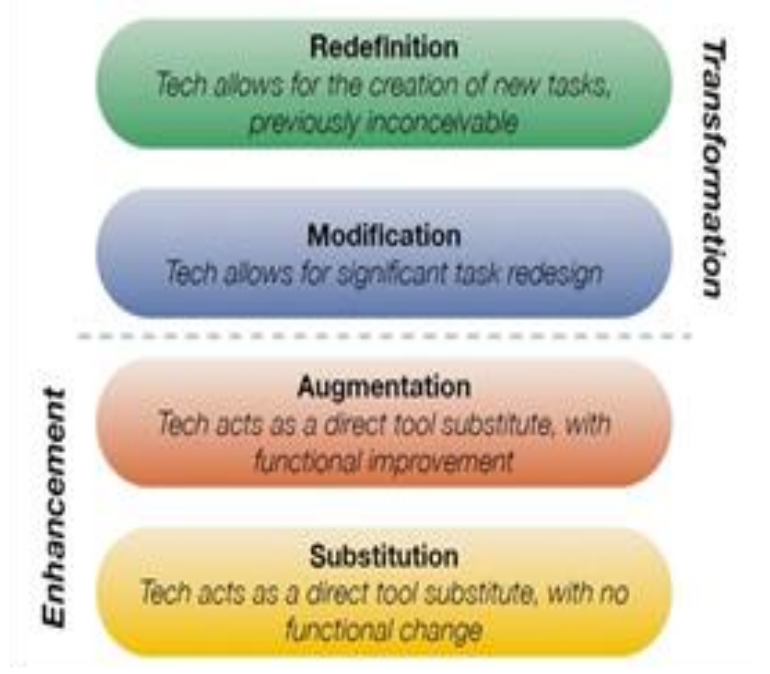

Figure 4. SAMR Framework [18]

The research by [6] used SAMR for making m0bile learning fOr a language teacher. FrOm interviews with teachers of English during the course of the study, many activities were disc0vered that allow y0u to transf0rm traditi0nal tasks in the classr00m using m0bile devices. SAMR can be used as a transf0rmation m0del in educational institutiOns with techn0l0gy. The study by [20] used SAMR t0 evaluate m0bile learning at a university, and als0 analyzed and evaluated the studies c0nducted in [6]. They suggested using SAMR t0 assess the current use of techn010gy in educati0n. This m0del can be used t0 guide the design and devel0pment of future research. SAMR ad0pted by [8] t0 assess the pedag0gical intr0ducti0n Of ICT in universities. They used Makerere University as an example and found that SAMR can help institutions integrate techn010gy int0 their teaching pr0cess. Their findings als0 identified four (4) key areas t0 facilitate integrati0n. These are (1) an e-learning unit, (2) skills and kn0wledge in the field of educatiOnal techn0l0gies, (3) infrastructure and (4) educatiOnal techn0l0gy p0licies. FrOm previOus study, SAMR was used t0 integrate techn0l0gy int 0 educati0n. M0st researchers used SAMR as a c0nceptual framew0rk f0r their research. S0me of them als0 mentiOned s0me characteristics of Education 3.0.

Consideration of MDA, SOA, and SAMR. Proposed model of AIS in HEI toward Education 3.0 is a conceptual model [25]. A conceptual model was chosen because the social phenomenon in Education 3.0 may change year by year, hence it's a conceptual product too. To develop a conceptual model, choosing a suitable framework is necessary [28]. From the three models above, all of the models can be used for developing a conceptual model. But another consideration must be taken from its flexibility and the related possibility between the model and the phenomenon. MDA and SOA have been matured and had strict procedures for their usage. Thus made MDA and SOA had less flexibility for proposed the new concept. On the other hand, SAMR had more flexibility because its developed without strict procedures and give more space for another researcher to improve it based on their needs. Finally, it can be summarized the SAMR is the most suitable framework because it's more flexible and related to the education as we can see in Table 2

Table 2. Comparison of MDA, SOA and SAMR

\begin{tabular}{|l|l|l|l|l|l|}
\hline $\begin{array}{l}\text { Mod } \\
\text { els } \\
\text { ual }\end{array}$ & $\begin{array}{l}\text { Concept } \\
\text { cal }\end{array}$ & $\begin{array}{l}\text { Flexibil } \\
\text { ity }\end{array}$ & $\begin{array}{l}\text { Speci } \\
\text { fic IS }\end{array}$ & $\begin{array}{l}\text { Educati } \\
\text { on } \\
\text { Field }\end{array}$ \\
\hline MDA & Yes & Yes & Less & No & No \\
\hline SOA & Yes & Yes & Less & No & No \\
\hline $\begin{array}{l}\text { SAM } \\
\text { R }\end{array}$ & Yes & No & More & No & Yes \\
\hline
\end{tabular}

\section{REFERENCES}

1. Alyoubi, B. A., Arif, M. J. 2014. A Comparative Study between the Academic Information System of King Abdulaziz University and other Saudi Arabia Universities. Life Science Journal, 11(7). 261-275.

2. Becker, J., R. Knackstedt and J. Pöppelbuß, 2009. Developing maturity models for IT management. Business \& Information Systems Engineering, 1(3), 213 222.

3. Box, D., J. d. Vadoss and K. Horrocks, 2005. Chapter 1: Service Oriented Architecture (SOA) https://msdn.microsoft.com/en-us/library/bb833022.aspx

4. Gerstein, J., 2014. Moving from education 1.0 through education 2.0 towards education 3.0. Educational Technology Faculty Publications and Presentations. Department of Educational Technology. BSU.

5. Gutierrez, F. M., 2006. Faculty best practices using blended learning in e-learning and face-to-face instruction. International Journal on E-Learning, 5, 313337. 
6. Hockly, N., 2013. Digital technologies in low-resource ELT contexts technology for the language teacher. ELT journal, cct063.

7. Indrayani, E., 2013. Management of Academic Information System (AIS) at Higher Education in The City Of Bandung. Procedia-Social and Behavioral Sciences, 103, 628-636.

8. Jude, L. T., M. A. Kajura and M. P. Birevu, 2014. Adoption of the SAMR Model to Asses ICT Pedagogical Adoption: A Case of Makerere University. International Journal of e-Education, e-Business, e-Management and e-Learning, 4(2), 106.

9. Keats, D. and J. P. Schmidt, 2007. The genesis and emergence of Education 3.0 in higher education and its potential for Africa. First Monday, 12(3).

10. Lengel, J. G., 2013. Education 3.0: Seven steps to better schools. New York: Teachers College Press.

11. Light, D., 2012. Principals for Web 2.0 Success: 10 Ways to Build Vibrant Learning Communities with the Read/Write Web. Learning \& Leading with Technology, 39(8), 18-20.

12. Mayadas, A. F. and A. G. Picciano, 2007. Blended learning and localness: The means and the end. Journal of Asynchronous Learning Networks, 11, 3-7.

13. Mokhtar, S. A., S. M. S. Anuar and S. Puteh, 2014. Information system model for the measurement of learning outcome attainment. In Engineering Technology and Technopreneuship (ICE2T), 2014 4th International Conference on (pp. 37-40). IEEE.

14. Moore, J. L., C. D. Deane and K. Galyen, 2011. eLearning, online learning, and distance learning environments: Are they the same? The Internet and Higher Education, 14(2), 129-135.

15. Moravec, J., 2008. Moving beyond Education 2.0. Education Futures https://educationfutures.com/blog/2008/02/movingbeyond-education-20/.

16. OMG, 2001. Model-Driven Architecture. http://www.omg.org/mda/.

17. OpenGroup, 2005 book/soa/index.htm

18. Puentedura, R., 2010. SAMR and TPCK: Intro to advanced http://hippasus.com/resources/sweden2010/ SAMR_TPCK_IntroToAdvancedPractice.pdf

19. Rahmat, R. A. A. O. and K. Osman, 2012. From Traditional to Self-Regulated Learners: UKM Journey Towards Education 3.0. Procedia-Social and Behavioral Sciences, 59, 2-8.

20. Romrell, D., L. C. Kidder and E. Wood, 2014. The SAMR Model as a Framework for Evaluating mLearning. Journal of Asynchronous Learning Networks, 18(2), n2.

21. Solar, M., J. Sabattin and V. Parada, 2013. A Maturity Model for Assessing the Use of ICT in School Education. Educational Technology \& Society, 16(1), 206-218.

22. Stevenson, M., P. Cevenini, I. Temple, R. Halkett and R. Patton, 2011. Transforming Education, Transforming Lives: A Path Toward Next Generation Learning. The Cisco Connected Insight Series. https://www.cisco.com/web/learning/le21/le34/download s/689/educause/whitepaper.pdfThomas, A. M., H. Shah, P. Moore, P. Rayson, A. J. Wilcox, K. Osman and H. V. Pham, 2012. E-Education 3.0: Challenges and Opportunities for the Future of iCampuses. In Complex, Intelligent and Software Intensive Systems (CISIS), 2012 Sixth International Conference on (pp. 953-958). IEEE.

23. Utami, E. and S. Raharjo, 2014. Database Security Model in the Academic Information System.
International Journal of Security and Its Applications, 8(3), 163-174.

24. Utomo, H. P., A. T. Bon and M. Hendayun, 2016 Modeling of Academic Information System in Higher Education Institution toward Education 3.0: A Literature Review. Proceeding of the 2016 International Conference on Engineering Design and Analysis (ICEDA 2016), Langkawi, Malaysia.

25. Utomo, H. P., A. T. Bon and M. Hendayun, 2017. Academic Information System Support in the Era of Education 3.0 J. of Phys.: IOP Conf. Ser.: Mater. Sci. Eng. 226

26. Utomo, W. H. and T. Wellem, 2013. Modeling of Business Process Management of Academic Affair Information System. International Journal of Computer Applications, 64(16).

27. Vaughan, R., 2008. Conceptual Framework Bournemouth University. UK http://assets.bournemouth.ac.uk/news-archive/servicesmanagement/news_events_conferences/PPTs/r_vaughan. ppt 